\title{
High Solid Anaerobic Co-Digestion of Household Organic Waste with Cow Manure for Mass and Energy Recovery
}

\author{
Nuruljannah Khairuddin'*, Latifah Abd Manaf', Mohd Ali Hassan², \\ Normala Halimoon ${ }^{1}$, Wan Azlina Wan Ab Karim Ghani ${ }^{3}$ \\ ${ }^{1}$ Department of Environmental Sciences, Faculty of Environmental Studies, Universiti Putra Malaysia, \\ 43400 UPM Serdang, Malaysia \\ ${ }^{2}$ Department of Bioprocess Technology and Bimolecular Sciences, Faculty of Biotechnology and Molecules, \\ Universiti Putra Malaysia, 43400 UPM Serdang, Malaysia \\ ${ }^{3}$ Department of Environmental Engineering, Faculty of Engineering, Universiti Putra Malaysia, \\ 43400 UPM Serdang, Malalysia
}

Received: 3 September 2015

Accepted: 20 February 2016

\begin{abstract}
This paper describes a batch study on four different mixture ratios of household organic waste and cow manure. The biomethane potential test is used to evaluate the suitability of high solid anaerobic co-digestion of household organic waste and cow manure and its biodegradability. The maximum methane yield was observed for both co-digestions in $\mathrm{R}_{3}(247 \mathrm{~mL} / \mathrm{g} \mathrm{VS})$ and $\mathrm{R}_{4}(244 \mathrm{~mL} / \mathrm{g} \mathrm{VS})$. The percentages of mass recovery were $65-80 \%$ (based on VS removal). The biodegradability of each reactor was recorded as $97.7 \%, 10.7 \%, 71.6 \%$ and $76.8 \%$ for $\mathrm{R}_{1}, \mathrm{R}_{2}, \mathrm{R}_{3}$, and $\mathrm{R}_{4}$, respectively. High solid co-digestion of household organic waste and cow manure in different mixture ratios increase the specific methane yields compared to mono-digestion. Hence, this clearly demonstrates a synergistic effect on the stability of anaerobic digestion. Upon correcting the results of the theoretical method with experimental data, an agreement ranged $70-90 \%$ was achieved.
\end{abstract}

Keywords: anaerobic co-digestion, biodegradability, biomethane potential, energy mass recovery, high solid anaerobic digestion

\section{Introduction}

Today, anaerobic digestion is widely applied to treat a diverse range of organic waste that promotes betterment in landfill management and produces a potential renewable

*e-mail: jannah.env@gmail.com energy source. Organic waste (mainly food waste) is very attractive and a potential feedstock for anaerobic digestion due to it high fraction in waste generation, especially in Malaysia. Moreover, the high composition of fat and lipids in organic waste contributes to higher conversion of organic matter in the waste fraction for biogas production. However, degradation of lipids and fats produces long- 
chain fatty acids (LCFAs) that inhibit and suppress the process. Anaerobic digestion of cow manure also is seen as unstable due to its low carbon:nitrogen ratio $(\mathrm{C}: \mathrm{N})$. Hence it is important to look forward the potential of codigestion approaches to organic waste - especially food waste and cow manure - for optimum and stable biogas production.

Lately, high solids digestion has gained rapid interest for treatment technology (HS-AD). High solid anaerobic digestion (HS-AD) is preferable because it requires minimal pre-treatment and added water compared to low solid anaerobic digestion (LS-AD) [1]. High solid anaerobic digestion is regularly described with the total solid (TS) greater than $15 \%(\mathrm{w} / \mathrm{w})$ [2]. A comprehensive review discussed on the advantages of HS-AD over LSAD supports HS-AD being able to operate under minimal water addition with technical simplicity, smaller reactor volume, and high quality of digested residue due to minimal nutrient loss during digestion [3]. Some studies are related to the application of HS-AD on different types of organic substrates, including organic fraction of municipal solid waste (OFMSW) [4-6], industrial organic residue [7-8], animal manure [9-10], biomass [11-12], and sewage sludge [13]. Although there is increasing interest in anaerobic co-digestion, so far less has been reported on the synergistic effect of co-digestion of high solid anaerobic digestion on source-sorted household organic waste (15\% TS) with cow manure (5\% TS).

The present work involves the application of codigestion of HS-AD in a single-phase system of sourcesorted household organic waste - mainly household organic waste (HOW) with cow manure (CM). The principal objective of this paper is to access the levels of material and energy recovery from household organic waste. We seek to evaluate the feasibility and performance of co-digestion HS-AD of HOW. We also have paid attention to the impact of implementing HS-AD for promoting recycling and reuse of organic substrate prior to sustainable landfill management.

\section{Materials and Methods}

\section{Preparation of Feedstock}

The HOW used in the current study is basically sampled from source-sorted household OFMSW (mainly food waste). Samples were collected, manually sorted, and shredded using a laboratory blender. Water was added to the desired total solid (15\% TS). CM was sampled from the Universiti Putra Malaysia (UPM) agricultural park. The feedstock was kept frozen $\left(-2^{\circ} \mathrm{C}\right)$ until required for feeding. Anaerobic inoculums used in this study were supplied by SPmultitech (SP Multitech Renewable Energy $\mathrm{Sdn}$ Bhd). The inoculum were thermophilic $\left(55^{\circ} \mathrm{C}\right)$ treated in an air-tight reactor before being introduced to the feedstock. The chemical characteristics of the feedstock and inoculums operated in this study are prescribed as in Table 1.
Table 1. Characteristics of feedstock and inoculums.

\begin{tabular}{|c|c|c|c|}
\hline Parameter & HOW & CM & Inoculum \\
\hline pH & 5.3 & 7.5 & 8.3 \\
\hline TS (\%) & 40.4 & 15.2 & 26.3 \\
\hline VS (\%) & 30.6 & 13.8 & 22.5 \\
\hline Moisture Content (\%) & 84.5 & 50.4 & 44.0 \\
\hline TOC (g) & 40 & 78.3 & 27.6 \\
\hline C:N & 11.0 & 11.2 & 25.3 \\
\hline Ammonia (g/L) & 4.3 & 26.88 & 14.8 \\
\hline Alkalinity (g/L) & 5.1 & 7.7 & 16.5 \\
\hline Total C (\%) & 59.2 & 35.4 & 35.4 \\
\hline Total H (\%) & 9.4 & 6.3 & - \\
\hline Total N (\%) & 5.4 & 5.8 & 1.4 \\
\hline Total S (\%) & 0.4 & 1.0 & - \\
\hline Total P (\%) & 18.5 & 0.18 & - \\
\hline Total K (\%) & 65.6 & 1.27 & - \\
\hline
\end{tabular}

\section{Experimental Design and Operation}

In this study, batch experiments were designed to evaluate the performance of high solid co-digestion of $\mathrm{HOW}$ and $\mathrm{CM}$ in four different mixing ratios. The assays were conducted in a $1 \mathrm{~L}$ batch scale reactor as depicted in Fig. 1 with total working volume of $800 \mathrm{~mL}$ incorporated with three separate ports for different functions of feeding inlet, biogas measurement, and biogas collection connected to a $1 \mathrm{~L}$ standard FlexFoil gas bag with single polypropylene fitting (SKC brand). The experimental designs and scheme are summarized in Table 2. Before starting anaerobic digestion, each reactor headspace was purged with pure $\mathrm{N}_{2}$ gas (99.9\%) for at least three minutes, and sealed with a rubber septum prior to incubation. Each digester was manually mixed once daily. The biogas production is measured periodically by the water displacement method and calculated as volume at standard temperature and pressure (STP) conditions.

\section{Analytical Procedures}

Substrate samples were analyzed twice a week to monitor total solids (TS), volatile solids (VS), alkalinity, total nitrogen (TKN), total organic carbon (TOC), chemical oxygen demand (COD), and ammonium nitrogen $\left(\mathrm{N}_{4}^{+}-\mathrm{N}\right)$. All the analytical monitoring was determined according to Standard Methods (2005) [14]. Elemental analysis such as total carbon, total nitrogen, and total sulfur were analyzed using AAS based on the liquid extraction method, whereas nitrogen, phosphorus, and potassium $(\mathrm{N}, \mathrm{P}$, and $\mathrm{K}$ ) were measured by the soil extraction method using a Mac CNS analyzer, and crude protein was determined by multiplying total nitrogen values by 6.25 . The biogas composition $\left(\mathrm{CH}_{4}\right.$ 


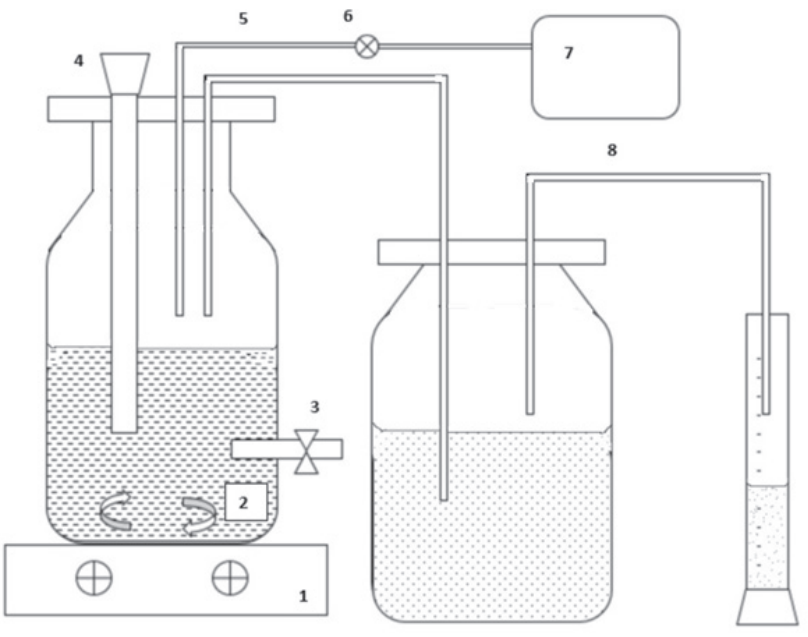

Fig. 1. Schematic diagram on batch experiments set-up. Hot plate with magnetic stirer 2) 1L Schott bottle 3) Effluent port 4) Feeding port 5) Gas-pipeline 6) Gas-pump 7) 1L Biogas bag 8) Water displacement measurement.

Table 2. Batch experimental design and scheme of feedstock and inoculum.

\begin{tabular}{|c|c|c|c|}
\hline \multirow{2}{*}{ Reactor } & \multicolumn{2}{|c|}{ Feedstock } & \multirow{2}{*}{$\begin{array}{c}\text { \% Inoculum } \\
(\mathrm{mL})\end{array}$} \\
\cline { 2 - 3 } & $\begin{array}{c}\mathrm{HOW} \\
(\mathrm{mL}, 15 \% \mathrm{TS})\end{array}$ & $\begin{array}{c}\mathrm{CM} \\
(\mathrm{mL}, 5 \% \mathrm{TS})\end{array}$ & \\
\hline $\mathrm{R}_{1}$ & - & 760 & 40 \\
\hline $\mathrm{R}_{2}$ & 760 & - & 40 \\
\hline $\mathrm{R}_{3}$ & 380 & 380 & 40 \\
\hline $\mathrm{R}_{4}$ & 506 & 254 & 40 \\
\hline
\end{tabular}

and $\mathrm{CO}_{2}$ ) analysis was carried out by gas chromatography separation (6890N Agilent Technologies, CA, USA) using a thermal conductivity detector (GC-TCD) equipped with a Hay sep N 80/100 and a molecular sieve column (5A 60/100). Argon (Ar) was used as carrier gas at a flow rate of $12 \mathrm{~mL} / \mathrm{min}$. The injector, oven, and detector temperatures were $105^{\circ} \mathrm{C}, 60^{\circ} \mathrm{C}$, and $150^{\circ} \mathrm{C}$, respectively. Methane generation yield was normalized by correcting the gas volume to STP.

\section{Theoretical Methane Yield (TMY $\left.{ }_{\text {ele }}\right)$ and Biodegradability $\left(\mathrm{BD}_{\text {ele }}\right)$}

Theoretical methane yield (TMY) is commonly expressed as $\mathrm{mL} \mathrm{CH}_{4}$ at STP conditions per amount of organic material added (VS- or COD-based). The assessments are basically estimated using the stoichiometric equation as simplified in Equation 1 based on Buswell formula and ( $\left.\mathrm{STP}=0^{\circ} \mathrm{C}, 1 \mathrm{~atm}\right)$ to determine the energy value of the feedstock [15-16]:

$$
T M Y_{\mathrm{ele}} \frac{m L C H 4}{g V S}=\frac{\left(\frac{a}{2}+\frac{b}{8}-\frac{c}{4}-\frac{3 d}{8}-\frac{e}{4}\right) \cdot 22400}{(12 a+b+16 c+14 d+32 e)}
$$

...where $a$ is the number of atoms of carbon, $b$ is the number of atoms of hydrogen, $c$ is the number of atoms of oxygen, $d$ is the number of atoms of nitrogen, and $e$ is the number of atoms of sulphur. Biodegradability $\left(\mathrm{BD}_{\text {ele }}\right)$ of the feedstock was measured based on measured experimental methane yield (EMY) and theoretical methane yield (TMY) as presented in Eq. (2) [17].

$$
B D_{\text {ele }}=\frac{\text { Measure BMP }}{\text { TMYele }}
$$

\section{Statistical Analysis}

To define the relationship between operational parameter and process performance on the synergistic effect, Pearson correlation coefficient $\left(\mathrm{R}^{2}\right)$ was determined and the significance of the study was verified using SPSS version 22.0 (SPSS, Inc, Chicago, USA).

\section{Results and Discussion}

\section{The Stability of High Solid \\ Anaerobic Digestion}

\section{pH Monitoring}

Fig. 2 shows $\mathrm{pH}$ trends for solid phase functioning of each reactor. At the beginning of digestion $\mathrm{pH}$ dropped drastically, causing the substrates to be suppressed as the organic substance was hydrolyzed and converted to fatty acids. Hydrolysis took place at this point, when $\mathrm{pH}$ started to show decrement. $\mathrm{pH}$ inconstancy was observed as a result of the production of fatty acids in the reactor, especially at the early stage of functioning. This is supported by a previous study that reported methanogenisis occurring effectively at $\mathrm{pH}$ 6.5-8.2 while hydrolysis and acidogenisis occur at $\mathrm{pH} 5.5$ and 6.5 [18]. $\mathrm{R}_{1}$ is maintained at the optimum $\mathrm{pH}$ values whereas $\mathrm{R}_{2}$ only reaches 6.4 for three consecutive days and drops dramatically, caused sourness. The $\mathrm{pH}$ values in $\mathrm{R}_{2}$ fell instantly at the start-up phase and reached a $\mathrm{pH}$ value of 5.3 on day 15 . The extreme $\mathrm{pH}$ decrement in $\mathrm{R}_{2}$ results in

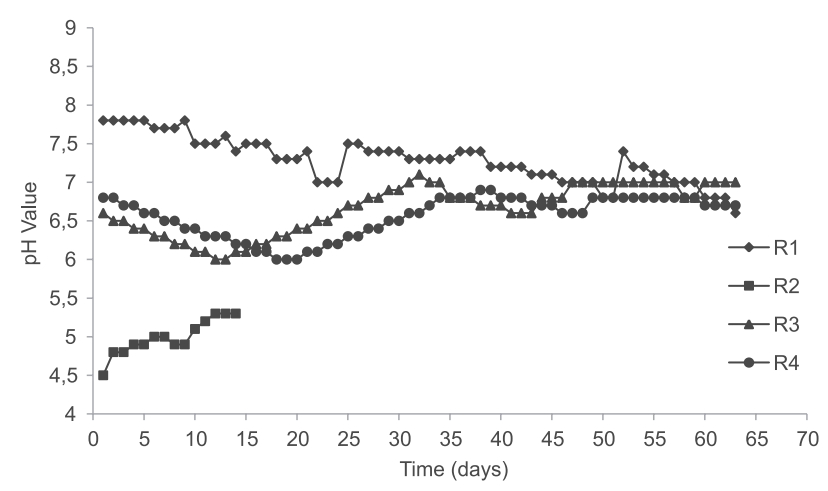

Fig. 2. Temporal $\mathrm{pH}$ variations with digestion times. 
methane production to suppression. Hence, the digestion process in $R_{2}$ was mainly limited to the first 15 days of functioning. At the short period of the acetogenesis stage the $\mathrm{pH}$ started to increase gradually as fatty acids were consumed by acetogens, and later at the methanogenesis stage by methanogens. At this phase, $\mathrm{pH}$ values from $\mathrm{R}_{3}$ and $\mathrm{R}_{4}$ during days 15-30 are stable and maintained while $\mathrm{R}_{1}$ showed drastic decrement. The average $\mathrm{pH}$ values in the study period were 4.5-7.

\section{Removal of VS and COD}

The periodical VS evolutions in each reactor are presented in Fig. 3. The degradation of feedstock was presented with the variation of VS patterns in this study. $\mathrm{R}_{2}$ showed a slight descent of VS removal during days 15-40 and reaching constant values until the finishing phase. $R_{3}$ and $R_{4}$ showed significant VS removal in several consecutive days of functioning (40-45 days). The percentage of VS removal attained $50 \%$ for $\mathrm{R}_{2}$ and more than $70 \%$ for $\mathrm{R}_{1}, \mathrm{R}_{3}$, and $\mathrm{R}_{4}$ in 60 days of operation. These results support the fact that approximately $65-80 \%$ of organic matters were removed in $R_{1}, R_{3}$, and $R_{4}$ within 45 days, whereas $R_{2}$ needed an additional 15 days of operation to achieve the same percentage of removal. COD concentration patterns in each of the reactors are reported in Fig. 4. High COD values were described in the initial process and started to decrease as organic matter in the substrate was utilized by methanogens $R_{3}$ and $R_{4}$. Satisfactorily, the COD values in each reactor decreased to approximately more than $80 \%$ of COD elimination during the functioning time. The initial COD concentrations were 6,879 mg COD/L, 10,587 mg COD/L, 7,380 mg COD/L, and 6,541 $\mathrm{mg} \mathrm{COD} / \mathrm{L}$ for $\mathrm{R}_{1}, \mathrm{R}_{2}, \mathrm{R}_{3}$, and $\mathrm{R}_{4}$, respectively. At the beginning of the process, slight decrements of COD concentrations were measured in the first week for $R_{1}$, $\mathrm{R}_{3}$, and $\mathrm{R}_{4}$, and $\mathrm{R}_{2}$ in the first two weeks. The decrement is due to the degradation of complex organic substrates at the initial phase of digestion without effecting COD concentration. The stability of anaerobic digestion mainly depends on the removal of soluble organics. High solid reduction is the indicator to measure efficiency and stability of a treatment system and operation. Elimination of organic matter is important to meet the standard

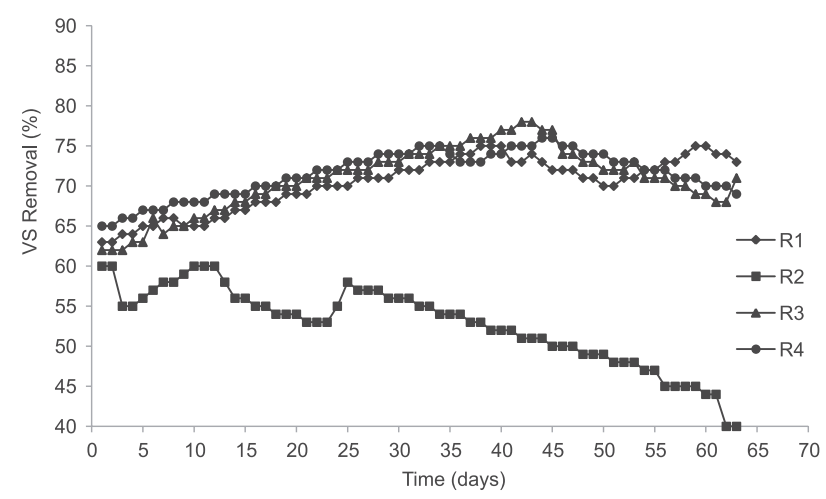

Fig. 3. Temporal VS patterns with digestion time.

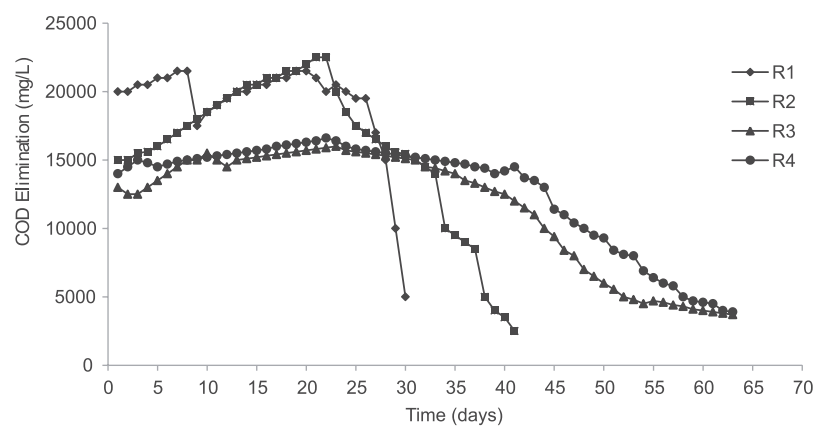

Fig. 4. Temporal COD eliminations with digestion times.

operation in a sanitary landfill. Hence, from monitoring, this study supports the stable operation of the co-digestion of high solid HOW and CM.

\section{Evolution of Methane Production}

Daily methane yield from each treatment was depicted as in Fig. 5. Methane production in $\mathrm{R}_{3}$ is the highest ( $247 \mathrm{~mL} \mathrm{CH}_{4} / \mathrm{g} \mathrm{VS}$ ) followed by $\mathrm{R}_{4}(244 \mathrm{~mL} / \mathrm{g} \mathrm{VS}$ ). All these mixtures obtained higher $\mathrm{CH}_{4}$ production than sole substrate in $\mathrm{R}_{1}(\mathrm{CM})$ and $\mathrm{R}_{2}$ (HOW), with $223 \mathrm{~mL} / \mathrm{g} \mathrm{VS}$ and $54 \mathrm{~mL} / \mathrm{g} \mathrm{VS}$, respectively. The digestion suppressed at the beginning of the process in $\mathrm{R}_{1}$ (11 days) and $\mathrm{R}_{2}$ a week (21 days) later caused the digestion to stop. Co-digestion in $\mathrm{R}_{4}$ increased $9 \%$ for $\mathrm{CM}$ and $78 \%$ for $\mathrm{HOW}$ in $\mathrm{CH}_{4}$ yield. Anaerobic digestion of monosubstrate was found to be unstable due to insufficient nutrient content [19]. The alkaline components of $\mathrm{CM}$ as co-substrate might have neutralized the $\mathrm{pH}$ in $\mathrm{R}_{3}$ and $\mathrm{R}_{4}$, thus improving the buffer capacity potential in both reactors. During stable phase methane production there were $237.9 \mathrm{~mL}, 74.4 \mathrm{~mL}$, $313.5 \mathrm{~mL}$, and $240.3 \mathrm{~mL}$ in approximately $15-35$ days of operation. The batch assays ended with a $\mathrm{CH}_{4}$ production less than $1 \%$ in 40 days of operation. Pearson correlation coefficient $\left(\mathrm{R}^{2}\right)$ between operational parameters and specific methane yield shows as described in Table 3. VS and COD are strongly correlated with specific methane yield followed by $\mathrm{pH}$, ammonium nitrogen, and total nitrogen. A previous study reported as total solid in substrate increases and that organic matter conversion by microorganism induced higher methane production [20]. $\mathrm{R}^{2}$ indicates a slightly stronger relationship between

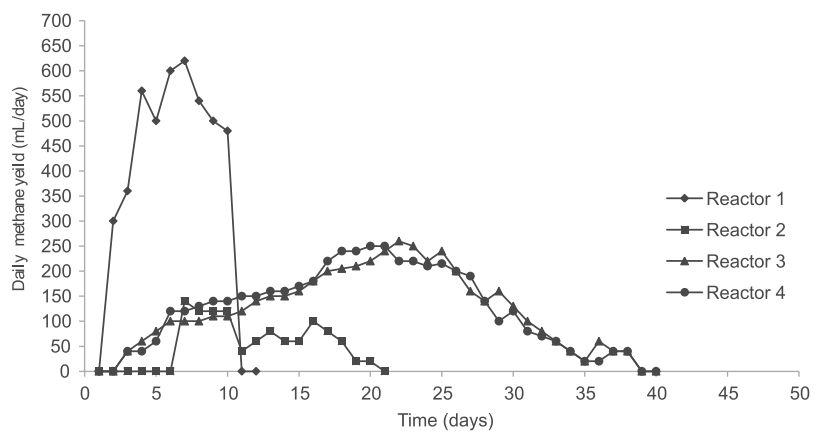

Fig. 5. Daily methane production in the reactors. 
Table 3. Relationships between main operational parameter and specific methane yield $\left(\mathrm{R}^{2}\right)$.

\begin{tabular}{|c|c|}
\hline Parameter & $R^{2}$ Pearson \\
\hline $\mathrm{pH}$ & 0.670 \\
\hline $\mathrm{COD}$ & 0.965 \\
\hline $\mathrm{VS}$ & 0.960 \\
\hline $\mathrm{N}_{4}^{+}-\mathrm{N}$ & 0.407 \\
\hline $\mathrm{TKN}$ & 0.233 \\
\hline
\end{tabular}

Correlation is significant at $<0.01$ level (2-tailed)

$\mathrm{pH}$ and specific methane yield due to the variation of HOW chemical characteristics. The optimum $\mathrm{pH}$ for methane production is 6.8-7.2. However, HOW is vulnerable to higher VFA production that promotes a decrease in $\mathrm{pH}$.

\section{Mass and Energy Recovery}

The potential of theoretical methodology to precisely estimate methane yield of anaerobic co-digestion was evaluated by comparing the experimental methane yields (EMY) with theoretical methane yields (TMY). Table 4 represents experimental production (EMY) and biodegradability $\left(\mathrm{BD}_{\text {exp }}\right)$. The methane yield from the experimental process is at more than $90 \%$ agreement with the theoretical methane yield estimation for $R_{3}$ and $R_{4}$. The maximum $\mathrm{CH}_{4}$ purity percentages were $65 \%$ and $55 \%$ for $\mathrm{R}_{3}$ and $\mathrm{R}_{4}$, respectively. The results showed different behaviors for $\mathrm{R}_{1}$ and $\mathrm{R}_{2}$ (sole-digestion), indicating that the synergistic effect is significant for anaerobic codigestion. Overall, it is ascertainable that theoretical estimation methods based on stoichiometric composition with biodegradability values have the potential to evaluate specific methane yields $R_{3}$ and $R_{4}$.
Mass recovery is widely calculated in two ways: by wet weight and on a VS basis. This study focuses on VS removal. HS-AD seems to be efficient in treating organic waste and significant mass and volume reduction of 60 $80 \%$ in each reactor. Higher VS reduction was observed in reactors with higher methane yield $\left(\mathrm{R}_{3}\right.$ and $\left.\mathrm{R}_{4}\right)$. More than $50 \%$ of VS removal was observed in the failed reactors, even though there was least methane production $(<10 \%)$. The estimation of important elements such as macromolecules $(\mathrm{N}, \mathrm{P}$, and $\mathrm{K}$ ) is crucial for further utilization of digestate. The AD added value to the digestate converts the organic portion of waste to compost, fertilizer, and soil amendments. Almost 5-30\% of nitrogen content was analyzed in digestate from each reactor. Complex nitrogen compounds are mineralized to ammonium $\left(\mathrm{N}_{4}^{+}-\mathrm{N}\right)$ during the digestion process. Most of the $\mathrm{N}_{4}^{+}-\mathrm{N}$ is utilized by microorganisms for AD metabolism. In the other hand, there is almost no effect of $\mathrm{AD}$ on phosphorus (P) availability in digestate (0.01-1.00\%). Increasing the $\mathrm{pH}$ enhanced the formation of phosphate $\left(\mathrm{HPO}_{4}^{-2} \rightarrow\right.$ $\mathrm{PO}_{4}^{3-}$ ) in the reactor. However, the mineralization stage during $\mathrm{AD}$ accumulates with a suspended solid, leading to precipitation of $\mathrm{P}$. Moreover, the highest increment of potassium $(\mathrm{K})$ content in digestate was observed in $\mathrm{R}_{2}(33 \%)$, followed by $\mathrm{R}_{3}(4.34 \%), \mathrm{R}_{1}(2.36 \%)$, and $\mathrm{R}_{4}$ $(2.1 \%)$.

\section{Conclusion}

Adapting the co-digestion of high-solid HOW with $\mathrm{CM}$ by using different mixture experimental design was established over a period of 9-10 weeks. The experimental methane yield was enhanced by 70-90\% (227-247 mL/g VS) from theoretical methane yield for $R_{1}, R_{3}$, and $R_{4}$, respectively. The maximum methane percentage was observed in a range of $55-75 \%$ from each reactor. The varied methane content

Table 4. Potential material and energy recovery.

\begin{tabular}{|c|c|c|c|c|c|}
\hline Recovery & Parameters & $\mathrm{R}_{1}(\mathrm{CM})$ & $\mathrm{R}_{2}(\mathrm{HOW})$ & $\mathrm{R}_{3}(1 \mathrm{HOW}: 1 \mathrm{CM})$ & $\mathrm{R}_{4}(2 \mathrm{HOW}: 1 \mathrm{CM})$ \\
\hline \multirow{6}{*}{ Mass } & VS Elimination (\%) & 80 & 67.3 & 77.3 & 71.2 \\
\hline & COD Removal (\%) & 27.3 & 76.4 & 52.6 & 46.5 \\
\hline & $\mathrm{N}(\%)$ & 28.6 & 7.4 & 14.6 & 17.5 \\
\hline & $\mathrm{P}(\%)$ & 0.01 & 0.01 & 1.1 & 0.01 \\
\hline & K $(\%)$ & 2.36 & 33.3 & 4.34 & 2.1 \\
\hline & Biodegradability & 97.7 & 10.7 & 71.6 & 76.8 \\
\hline \multirow{4}{*}{ Energy } & Daily $\mathrm{CH}_{4}(\mathrm{~mL})$ & $90-600$ & $11-149$ & $20-371$ & $20-307$ \\
\hline & Maximum $\mathrm{CH}_{4}(\%)$ & 75 & $<10$ & 65 & 55 \\
\hline & TMY (mL/g VS) & 232.29 & 505.17 & 345.17 & 317.7 \\
\hline & EMY (mL/g VS) & 227 & 54 & 247 & 244 \\
\hline
\end{tabular}

TMY: Theoretical Methane Yield (Eqs. 1 and 2)

EMY: Experimental Methane Yield 
in all reactors was likely due to homogeneity of the feedstock.

The experiment ended after day 40 of operation with VS elimination ranging $65-80 \%$ from each reactor.

\section{Acknowledgements}

The authors would like to acknowledge the Ministry of Science and Technology (MOSTI) of Malaysia and the University Putra Malaysia for financial support and laboratory facilities to conduct this research under project No. 06-01-04-SF1514.

\section{References}

1. DEBAERE L. Anaerobic digestion of solid waste: State-ofthe-art. Water Sci. Technol. 41, 3, 2000.

2. RAPPORT J., ZHANG R., JENKINS BM., WILLIAM RB. Current anaerobic digestion technologies used for treatment of municipal organic solid waste. California Environmental Protection Agency, 2008. Accessed in 10 Jan 2015. Available at; http://www.ca;recycle.ca.gov/Publications/ Organics/2008011.pdf.

3. KARTHIKEYAN O.P., VISVANATHAN C. Bioenergy recovery from high-solid organic substrates by anaerobic bio-conversion processes: a review. Rev. Environ. Sci. Biotechnol. 12, 3, 2013.

4. FOSTER-CARNEIRO T., PEREZ M., ROMERO LI. Influence of total solids and inoculum contents on performance of anaerobic reactors treating food waste. Bioresour. Technol. 99, 15, 2008.

5. MONTERO B., GARCIA-MORALES J.L., SALES D., SOLERO R. Evolution of microorganism in thermophilic dry anaerobic digestion. Bioresource Technol. 99, 8, 2008.

6. DONG L., ZHENHONG Y., YONGMING S. Semi-dry mesophilic anaerobic digestion of water sorted organic fraction of municipal solid waste (WS-OFMSW). Bioresource Technol. 101, 8, 2010.

7. GUENDOUZ J., BUFFIERE P., CACHO J., CARRERE M., DELGENES JP., ESCUDIE R. Dry anaerobic anaerobic digestion in batch mode: design and operation of a laboratory scale, completely mixed reactor, Waste Manage. 30, 10, 2010.

8. ZAHEDI S., SALES D., ROMERO L., SOLERO R. Optimization of single-phase dry-thermophilic anaerobic digestion under high organic loading rates of industrial; municipal solid waste: population dynamics. Bioresource Technol. 146, 2013.

9. ABOUELENIEN F., KITAMURA Y., NISHIO N., NAKASHIMADO Y. Dry anaerobic ammonia-methane production from chicken manure. Appl. Microbiol. Biotechnol. 82, 4, 2009.

10. AHN H.K., SMITH M.C., KONDRAD S.I., WHUTE J.W. Evaluation of biogas production potential by dry anaerobic of switch grass-animal manure mixture. Appl. Biochem. Biotechnol. 160, 4, 2010.

11. NIZAMI A.S., MURPHY J.D. What Type of digester configuration should be employed to produce biomethane from grass silage? Renew Sustain Energy Rev. 14, 6, 2010.

12. SCHMIDT T., PROTER J., SCHOLWIN F., NELLES M. Anaerobic digestion of grain stillage at high organic loading rates in three different reactor systems. Biomass and Bioenergy. 55, 8, 2013.

13. DUAN N., DONG B., WU B., DAI X. High solid anaerobic digestion of sewage sludge under mesophilic conditions: feasibility study. Bioresource Technol. 104, 2012.

14. APHA, 2005. Standard methods for the examination water and wastewater, $21^{\text {st }}$ ed. American Public Association, America Water Works Association, Washington, DC, USA.

15. 15. BUSWELLAM., MUELLER HF. Mechanism of methane fermentation. Industrial and Engineering Chemistry.44, 3, 1952.

16. LI Y., ZHANG R., CHEN C., LIU G., HE Y., LIU X. Biogas production from co digestion of corn stover and chicken manure under anaerobic wet, hemi-solid and solid state conditions. Bioresource Technol. 149, 2013.

17. EL BESHBISHY E., NAKHLA G., HAFEZ H. Biochemical methane potential (BMP) of food waste and primary sludge: Influence of inoculum pre-incubation and inoculum source. Bioresource Technol. 110, 2012.

18. LEE M., HIDAKA T., HAGIWARA W., TSUNO H. Comparative performance and microbial diversity of hyperthermophilic and thermophilic co-digestion of kitchen garbage and excess sludge. Bioresource Technol. 100, 4, 2009.

19. LI Y., PARK SY., ZHU J. Solid state anaerobic digestion for methane production from organic waste. Renew Sustain Energy Rev. 15, 1, 2011.

20. ZHENG Y., ZHONGLI P., ZHANG R., EL-MASHAD HM., PAN J., JENKINS BM. Anaerobic digestion of saline creeping with ryegrass for biogas production and pretreatment of particleboard material. Bioresource Technol. 100, 4, 2009. 